\title{
"Mutual fund acts as an investment consultant in the challenging financial market"
}

\author{
Prof. Naila Iqbal \\ Astt.Prof, Management Deptt, Rajiv Gandhi College, Bhopal
}

\begin{abstract}
Mutual Funds Emerged as an opportunity for small investors to earn money with limited money and knowledge of market scenario all over the world. The concept of Mutual Funds represents the most appropriate investment opportunity for small investors, as financial markets become more sophisticated and complex; investors need a financial intermediary who provides the required knowledge and professional expertise on successful investing. Mutual Fund originated in the USA and moving to the UK in the 1930, this culture started in India in 1960, with the setting up of UTI in 1964.Public sector bank and financial institutions began to establish mutual fund in 1987.The private sector and foreign Institutions were allowed to set up mutual funds in 1993.In a mutual fund the savings of many investors are combined to form a fairly large and well diversified portfolio of investments. The Indian Mutual Fund industry has already opened up many exciting investment opportunities to Indian investors. As a result we have started witnessing the phenomenon of more savings now being entrusted in Funds.
\end{abstract}

\section{Introduction}

A mutual fund is a special type of investment institution which acts as an investment consultant. It pools the savings of relatively small investors them in a well-diversified portfolio of sound investment. Mutual funds issue securities (know as units) to the investors (know as unit-holders) in accordance with the quantum of money invested by them. The profits (or losses) are shared by the investors in proportion to their investments. A mutual fund is set up in the form of a trust which has (i) a sponsor, (ii) trustees, (iii) Asset management company (AMC) and (iv) custodian.

\section{Objectives Of A Mutual Fund}

The objectives to be achieved by Mutual Fund Industry are as follows:

- To provide an opportunity for lower income groups to acquire property without much difficulty in the form of shares.

- To cater mainly the need of individual investors whose means are small.

- To manage investors' portfolios in a manner that provides regular income, growth, safety, liquidity and diversification enforcement.

III. Factors Influencing The Speedy Growth Of Mutual Fund Industry In India

On observing the past trends, it can be seen that certain factors are essential for the growth of Mutual Fund Industry. These factors are as follows:

i. Investor Base

A mutual fund expert on the basis of the investors' requirement invests their pooling into different fields on the basis of their expertise knowledge. As the small investors cannot diversify on their own; their presence acts as a catalyst for the mutual funds to grow.

ii. Returns on Market

Mutual fund returns generated are generally reflective of the market reurns.Higher the expected market returns, higher is the expected returns from a mutual fund. Higher returns attract more investors.

iii. Investment Avenues

The presence of certain investment avenues makes mutual funds more attractive than direct return. Investment avenues like money market instruments, investment in real states, securitized debt instrument, derivatives etc.all require expertise and upgraded knowledge which the investors lack therefore the mutual fund experts work on behalf of them.

iv. Objectivity of the Fun

The nature of the funds is clear that whether they are income oriented or growth oriented.

Income funds have a fixed interest whereas the growth funds have more returns with the higher risk. Depending on the risk factor the funds are chosen for investment.

v. Consistency of performance 
Investors are satisfied with a fund that shows a steady and consistent performance than a fund which performs well in one year and fails in the next year. Consistency in performance is a good indicator of its investment expertise.

\section{vi. Cost of Operation}

Mutual Funds seek to do better job of the investible funds at a lower cost than the individuals could not do for themselves. Higher the ratio, lower will be the actual returns to the investor and visa-vise

vii. Capacity for innovation

The investor will always look for funds which are capable of introducing innovations in the financial market i.e. the mutual funds are always up to introduce new schemes based on the market requirement.

viii. Transparency of the Fund Management

The mutual fund experts disclose the complete details regarding the operation of the funds to the investors; as a result investors are fully aware of their schemes in which their funds are invested .This results in the increase of faith in the mutual fund management.

\section{Significant Features Of Progress Of Mutual Fund Industry In India}

The mutual fund industry has grown at a phenomenal rate in the recent past. The following are some of the significant features of mutual funds:

- Channelizing savings for investment:

A number of schemes are being offered by MFs so as to meet the varied requirements of the peoples and savings are directed towards capital investments directly. In the absence of MFs these savings would have remained idle.

- Offering wide portfolio investment:

Now the investors can enjoy the wide portfolio investment held by the mutual fund. The fund diversifies its risks by investing in large varieties of shares and bonds which cannot be done by small and medium investor. This is investors. This is in accordance with the maximum 'not to lay all eggs in one basket

- Providing better yields:

Due to the large funds Mutual funds are able buy cheaper and sell dearer than the small and medium investors. Thus they are able to the command better market rates and lower rates of brokerage. So they provide better yield to their customers .they also enjoy the economics of large scale and can reduce the cost of capital market participation

- Rendering expertise investment service at low cost:

The management of the fund is generally assigned to professionals who are well trained and have adequate experience in the field of investment. Thus, investor are assured of quality services in there best interest. The intermediation fee is the lowest being $1 \%$ in the case of a mutual fund.

- Providing research services:

Each fund maintains large research team, which constantly analyses the companies and the industries and recommends the fund to buy or sell a particular share. Thus investments are made purely on the basis of a thorough research.

- Offering tax benefits:

Certain funds offer tax benefits to its customers. Thus, apart from dividend, interest and capital appreciation, investors also stand to get the benefit of tax concession. Under the wealth tax act, investments in MFs are exempted up to Rs. 5 lakhs.

- Introducing flexible investment schedule:

Some mutual funds are permitted the investor exchange their units from one schemes to another and this flexibility is a great boon to investors.

- Providing greater affordability and liquidity:

Even a very small investor can afford to invest in mutual funds. They provide an attractive and cost effective alternative to direct purchase of shares. Again there is greater liquidity. Units can be sold to the fund at any time at the net asset value and thus quick access to liquid cash is assured. Besides, branches of the sponsoring bank are always ready to provide loan facility against the unit certificates.

- Simplified record keeping:

The investor has to keep a record of only one deal with the mutual fund. Even if he does not keep a record, the MF sends statements very often to the investors.

\section{- Supporting capital market:}


The savings of the people are directed towards investments in capital market through these mutual funds. Mutual funds also provide a valuable liquidity to the capital market, and thus the market is made very active and stable.

- Promoting industrial development:

All industrial units have to raise their funds by resorting to the capital market by the issue of shares and debentures. The mutual funds not only create a demand for these capital market instruments but also supply a large source of funds to the market.

- Diversification: The best mutual funds design their portfolios so individual investments will react differently to the same economic conditions. For example, economic conditions like a rise in interest rates may cause certain securities in a diversified portfolio to decrease in value. Other securities in the portfolio will respond to the same economic conditions by increasing in value. When a portfolio is balanced in this way, the value of the overall portfolio should gradually increase over time, even if some securities lose value.

- Professional Management: Most mutual funds pay topflight professionals to manage their investments. These managers decide what securities the fund will buy and sell. Mutual funds are managed and supervised by investment professionals. As per the stated objectives along with prevailing market conditions and other factors, the mutual fund manager will decide when to buy or sell securities. This eliminates the investor of the difficult task of trying to time the market.

- Convenient administration: You can usually buy mutual fund shares by mail, phone, or over the Internet. Although a fund's shareholder is relieved of the day-to-day tasks involved in researching, buying, and selling securities, an investor will still need to evaluate a mutual fund based on investment goals and risk tolerance before making a purchase decision. Investors should always read the prospectus carefully before investing in any mutual fund.

- Transparency: Regulations for mutual funds have made the industry very transparent. You can track the investments that have been made on your behalf and the specific investments made by the mutual fund scheme to see where your money is going. In addition to this, you get regular information on the value of your investment.

\section{Scope Of Mutual Fund Business In India}

A mutual fund is the most suitable investment for the common man as it offers an opportunity to invest in a diversified, professionally managed basket of securities at a relatively low cost. India has a huge population of middle class estimated approximately around 300 million. A typical Indian middle class family can have liquid savings from Rs 2 Lacs to 10 Lacs. Investment in banks is liquid \& safe, but with the falling rate of interest offered by banks on deposits, it is no longer attractive. Mutual fund is the ready answer.

Though there are alternative mutual funds like investment in equities \& bonds or corporate deposits. But there is the big risk attached to these \& which will solely be beared by investor depending upon his amount of investment. While risk cannot be eliminated completely in mutual funds investment, skillful management of investment can at least minimize risk. Mutual funds help to reduce risk though diversification \& professional management. The experience \& expertise of mutual fund managers in selecting fundamentally sound securities $\&$ timing their purchases $\&$ sales help them to build a diversified portfolio that minimizes risk \& maximizes returns.

\section{Conclusion}

Viewed in this sense globally India is one of the best markets for mutual fund business. This is the reason that foreign companies compete with one another mutual fund business units in India. The sheer magnitude of the population of educated white collar employees provides unlimited scope for development of mutual fund business in India. Thus, with the emphasis on increase in domestic savings \& improvements in deployment of investment through markets, the need \& scope for mutual funds operations has increased tremendously.

\section{Bibliography}

[1]. Bhole L M, "Financial Institutions and markets", Tata McGraw-Hall, New Delhi, 1999

[2]. Khan M Y, "Indian Financial System, Tata Mc Graw-Hill, New Delhi, 2001.

[3]. S. Gurusamy, Financial markets and Institutions, Thomson publications, First Edition, 2004.

[4]. Pandey I M, Financial Management, Vikas Publications, New Delhi, 2000.. Mishra R K, An Overview of financial services, financial services, emerging trends, Delta, Hyderabad, 1997.

[5]. Mishra R K, "Development of financial services in India some perspectives", Financial services in India Delta, Hyderabad, 1998.

[6]. Mishra R K, "Global financial services Industry and the specialized financial services institutions in India, Utkal University, 1997.

[7]. www.rbi.org.inwww.sebi.gov.in

[8]. www.indiainfoline.com 